\title{
How do channel densities and various time constants affect the dynamic gain of a detailed model of a pyramidal neuron?
}

\author{
David Hofmann ${ }^{1,2^{*}}$, Andreas Neef ${ }^{1,2}$, Ilya Fleidervish ${ }^{3}$, Michael Gutnick ${ }^{4}$, Fred Wolf ${ }^{1,2}$ \\ From Twenty Second Annual Computational Neuroscience Meeting: CNS*2013 \\ Paris, France. 13-18 July 2013
}

The axon initial segment (AIS) controls the transformation of dendrosomatic synaptic input into spike output and the backpropagation of action potentials into the dendrites due to its lower spike initiation threshold. Channel density and kinetics can both contribute to this low threshold. However, the nature of such threshold differences is unknown and topic of current debates [1-3].

Dynamical response properties give a constraint on the AIS function. Here we study the dynamical response properties of a detailed multi compartment NEURON [4] model that well reproduces the sodium concentration changes in the AIS and soma generated by action potential firing in a layer 5 pyramidal cell [2].

To study these properties, we inject different current stimuli into the soma. These are constant currents and Gaussian noise currents as studied in [5]. We vary the sodium and potassium channel densities at the axon initial segment as well as the sodium activation time constant taum. Furthermore, we study the influence of input current parameters as mean, variance and correlation time. We then calculate the dynamic rate response of a population of independent neurons. This is described at linear order by a filter function with frequency dependent gain as done by [5].

The f-I curves show that the neuron model under investigation is of type I. This holds true for all channel densities tested. The cut-off frequency appears insensitive to AIS channel density.

* Correspondence: david@nld.ds.mpg.de

${ }^{1}$ Bernstein Center for Computational Neuroscience Göttingen, Germany

Full list of author information is available at the end of the article

\section{Author details}

'Bernstein Center for Computational Neuroscience Göttingen, Germany. ${ }^{2}$ Max Planck Institute for Dynamics and Self-Organization, Göttingen, Germany. ${ }^{3}$ Ben-Gurion University of the Negev, Israel. ${ }^{4}$ Hebrew University of Jerusalem, Israel.

Published: 8 July 2013

\section{References}

1. Maarten HPKole, Susanne Ullschner, Björn MKampa, Stephen RWilliams, Peter CRuben, Greg JStuart: Action potential generation requires a high sodium channel density in the axon initial segment. Nature Neuroscience 2008, 11(2): 178-86.

2. Ilya AFleidervish, Nechama Lasser-Ross, Michael JGutnick, William NRoss: Na + imaging reveals little difference in action potential-evoked $\mathrm{Na}+$ influx between axon and soma. Nature Neuroscience 2010, 13(7):852-860.

3. Chris GDulla, John RHuguenard: Who let the spikes out? Nature Neuroscience 2009, 12(8):959-60

4. Carnevale NT, Hines ML: The NEURON book Cambridge University Press; 2006.

5. Matthew HHiggs, William JSpain: Conditional bursting enhances resonant firing in neocortical layer 2-3 pyramidal neurons. The Journal of Neuroscience 2009, 29(5):1285-99.

doi:10.1186/1471-2202-14-S1-P419

Cite this article as: Hofmann et al:: How do channel densities and various time constants affect the dynamic gain of a detailed model of a pyramidal neuron? BMC Neuroscience 2013 14(Suppl 1):P419.

Submit your next manuscript to BioMed Central and take full advantage of:

- Convenient online submission

- Thorough peer review

- No space constraints or color figure charges

- Immediate publication on acceptance

- Inclusion in PubMed, CAS, Scopus and Google Scholar

- Research which is freely available for redistribution

Submit your manuscript at www.biomedcentral.com/submit 